Article

\title{
Effects of Osthole on Progesterone Secretion in Chicken Preovulatory Follicles Granulosa Cells
}

\author{
Na Sun ${ }^{1, \dagger}$, Yutong Zhang ${ }^{1,+}$, Yaxin Hou ${ }^{1}$, Yanyan $\mathrm{Yi}^{1}{ }^{1}$, Jianhua Guo ${ }^{2}$, Xiaozhong Zheng ${ }^{3}$, \\ Panpan Sun ${ }^{4}$, Yaogui Sun ${ }^{1}$, Ajab Khan ${ }^{1}$ and Hongquan Li ${ }^{1}$ ** \\ 1 College of Veterinary Medicine, Shanxi Agricultural University, Jinzhong 030801, China; \\ snzh060511@126.com (N.S.); zhangyutong5566@163.com (Y.Z.); houyaxinxt@163.com (Y.H.); \\ yieryan2015@163.com (Y.Y.); dkyypb@163.com (Y.S.); drajab22@gmail.com (A.K.) \\ 2 Department of Veterinary Pathobiology, College of Veterinary Medicine \& Biomedical Sciences, \\ Texas A\&M University, College Station, TX 77843, USA; jguo@cvm.tamu.edu \\ 3 Centre for Inflammation Research, Queen's Medical Research Institute, The University of Edinburgh, \\ Edinburgh EH16 4TJ, UK; Xiaozhong.Zheng@ed.ac.uk \\ 4 Laboratory Animal Center, Shanxi Agricultural University, Jinzhong 030801, China; sunpp0505@163.com \\ * Correspondence: lhqxzxx@sxau.edu.cn; Tel.: +86-0354-6289210 \\ + These authors contributed equally to this work.
}

Received: 8 October 2020; Accepted: 28 October 2020; Published: 4 November 2020

check for updates

Simple Summary: Progesterone produced by granulosa cells regulates the diverse reproductive events in poultry. Osthole is a natural compound extracted from Cnidium. In this study, we confirmed Osthole up-regulated the progesterone secretion though elevating the expression of key proteins in the process of progesterone synthesis. These results indicate Osthole could be used in the pre-peak phase and (or) the peak phase to maximize the output of egg production in laying hens. Moreover, it provided a new idea that natural compounds may be the target library to screen the potential drugs used in poultry to increase the egg quality and yield.

\begin{abstract}
Osthole (Ost) is an active constituent of Cnidium monnieri (L.) Cusson which possesses anti-inflammatory and anti-oxidative properties. It also has estrogen-like activity and can stimulate corticosterone secretion. The present study was aimed to check the role of Ost on progesterone (P4) secretion in cultured granulosa cells obtained from hen preovulatory follicles. Different concentrations $(5,2.5$, and $1.25 \mu \mathrm{g} / \mathrm{mL})$ of Ost was added to granulosa cells for $6,12,18$, and $24 \mathrm{~h}$ to investigate the level of progesterone secretions using enzyme linked immunosorbent assay (ELISA). The results showed that progesterone secretion was significantly increased in cells treated with Ost at $2.5 \mu \mathrm{g} / \mathrm{mL}$. Also, qRT-PCR showed that mRNA expression of steroidogenic acute regulatory protein (StAR) was significantly up-regulated by Ost at $2.5 \mu \mathrm{g} / \mathrm{mL}$ concentration. Cytochrome P450 side-chain cleavage (P450scc) and $3 \beta$-hydroxysteroid dehydrogenase (3 $\beta$-HSD) was significantly up-regulated by Ost. However, no significant differences were observed for the expression of proliferating cell nuclear antigen (PCNA). The protein expression of StAR, P450scc and 3 $\beta$-HSD were significantly up-regulated by Ost treatment. The concentration of cyclic adenosine monophosphate (cAMP) and protein kinase A (PKA) in cell lysates showed no change with Ost treatment at $2.5 \mu \mathrm{g} / \mathrm{mL}$ by ELISA. An ROS kit showed non-significant difference in the level of reactive oxygen species (ROS). In conclusion, Ost treatment at a concentration of $2.5 \mu \mathrm{g} / \mathrm{mL}$ for $24 \mathrm{~h}$ had significantly up-regulated P4 secretion by elevating P450scc, $3 \beta-\mathrm{HSD}$ and StAR at both gene and protein level in granulosa cells obtained from hen preovulatory follicles.
\end{abstract}

Keywords: osthole; progesterone; chicken preovulatory follicles granulosa cell 


\section{Introduction}

With the rapid development of the poultry and egg industry, people are now focusing on the production and quality of eggs. In order to increase egg production, amoxicillin, ciprofloxacin and other drugs were used to prevent avian epidemics and increase egg production which has caused drug residues in eggs [1]. Moreover, due to indiscriminate use and inappropriate higher doses, antimicrobial drugs result in an accumulation of harmful residues in edible tissues of poultry which are potential direct threats to humans in the form of toxicity [1]. Due to ban of antibiotics in poultry feed, the world is now in search of new methods to improve egg production and quality.

Traditional Chinese medicines have been used for centuries to prevent and cure diseases. The main bioactive component Osthole is isolated from the seeds of Cnidium monnieri (L.) Cusson having many biological effects, such as anti-oxidant, anti-inflammatory and anti-cancer activities [2]. Furthermore, Osthole had an estrogen-like effect and promoted the corticosterone biosynthesis and secretion $[3,4]$.

Progesterone (P4) plays a crucial part in ovulation which is regulated by luteinizing hormone in pre-ovulatory surge. Follicles in ovary are divided into four types, including small white follicles, large white follicles, small yellow follicles and pre-ovulatory follicles [5]. In hens, P4 is solely produced by the granulosa cells obtained from pre-ovulatory follicles [6,7]. Synthesis of progesterone is initiated by the transfer of cholesterol from the outer mitochondrial membrane to the inner one by steroid acute regulatory proteins (StAR) $[8,9]$. Cytochrome P450 cholesterol side chain cleavage (P450scc) converts cholesterol into pregnenolone which runs out of the mitochondria and enters into smooth endoplasmic reticulum and is thus converted into progesterone by $3 \beta$-hydroxysteroid dehydrogenase (3ß-HSD) [10,11].

In addition to direct effects on the process of progesterone synthesis, there are many other reasons which can indirectly affect the synthesis of progesterone. The proliferation of granulosa cells is closely related to the secretion of P4 [12,13]. Proliferating cell nuclear antigen (PCNA) plays an essential role in initiating cell proliferation and is thus a good indicator of cell proliferation [14]. P4 is a steroid hormone and its synthesis is mainly regulated by gonadotropins (e.g., follicle stimulatine hormone and luteinizing hormone) through a classical cAMP/PKA pathway. Intracellular cyclic adenosine monophosphate (cAMP) is activated by gonadotropins which causes the activation of protein kinase $\mathrm{A}$ (PKA) and specific transcription factors [15,16], resulting in the transcription and expression of steroid hormone-related proteins such as StAR and P450scc. Moreover, it is widely reported that reactive oxygen species (ROSs) inhibit steroidal hormone synthesis by robbing electrons [17-19].

In the current study, we investigated whether Ost up-regulated the secretion of P4 and explored the molecular mechanism involved.

\section{Materials and Methods}

\subsection{Isolation and Culture of Granulosa Cells}

All animal experiments were performed under the regulation and guidelines of Animal Ethical Committees of Shanxi Agricultural University (Taigu, China) (Ethical code: SXAU-EAW-2020C0201). The chicken pre-ovulatory follicle granulosa cells were isolated according to the method described by Gilbert et al. with minor modifications [20]. In brief, the ovarian tissue from 200-day-old Hylan brown layer chickens with a laying rate of more than $90 \%$ were collected and washed with phosphate buffer saline (PBS)three times. Follicles larger than $9 \mathrm{~mm}$ were put onto a glass dishes, and the granulosa and theca layer were separated rapidly. After washing three times with PBS, the granulosa layers were cut into pieces (less than $1 \mathrm{~mm}^{3}$ ), placed in an ampoule containing $12.5 \mathrm{mg} / \mathrm{mL}$ of collagenase type II and incubated for $5 \mathrm{~min}$ at $37^{\circ} \mathrm{C}$. An equal volume of pre-cooled M199 medium (Thermo fisher, Suzhou, Jiangsu, China) was added to inactivate collagenase type II. The digested granulosa layer was filtered through a $200 \mu \mathrm{m}$ mesh, centrifuged at $1000 \mathrm{rpm}$ for $8 \mathrm{~min}$. The harvested cells were washed twice with M199 medium and trypan blue staining was used to determine the cell viability. Granulosa cells were grown in M199 medium containing 10\% fetal bovine serum (FBS) (Sijiqing, Hangzhou, Zhejiang, 
China) and $1 \%$ penicillin-streptomycin for $24 \mathrm{~h}$ at $37^{\circ} \mathrm{C}$ and $5 \%$ atmospheric $\mathrm{CO}_{2}$. The grown cells were then used for the subsequent experiments and analysis. In the following experiment, four layer chickens were used to obtain enough granulosa cells.

\subsection{Identification of Granulosa Cells by Immunofluorescence}

First, $0.5 \mathrm{~mL}$ granulosa cells with a density of $8 \times 10^{5} / \mathrm{mL}$ were seeded into each laser scanning confocal dishes with 10\% FBS and 1\% penicillin-streptomycin mixed in M199 and incubated for $24 \mathrm{~h}$. To block the granulosa cells, 3\% BSA was used for $20 \mathrm{~min}$ at $37^{\circ} \mathrm{C}$. Follicle-stimulating hormone receptor (FSHR) rabbit polyclonal antibody (Proteintech, Wuhan, Hubei, China; Catalog number: 22665-1-AP) was added as the primary antibody and incubated for $2 \mathrm{~h}$ at $37^{\circ} \mathrm{C}$. The medium was discarded and cells were washed with PBS (three times) and incubated with second antibody-Mouse Anti-rabbit IgG/FITC antibody (Proteintech, Wuhan, Hubei, China) for immunofluorescence staining. Nuclei were stained with DAPI (Beyotime, Shanghai, China).

\subsection{Cell Viability}

Ost was purchased from National Institutes for Food and Drug Control (NIFDC), China with 99.6\% purity. Granulosa cells $(0.1 \mathrm{~mL})$ with a density of $8 \times 10^{5} / \mathrm{mL}$ in $10 \%$ FBS and $1 \%$ penicillin-streptomycin mixed in M199 were seeded into 96-well-plate and incubated for $24 \mathrm{~h}$. Ost was dissolved in 1\% dimethyl sulfoxide (DMSO), and diluted to various concentrations (80, 40, 20, 10, 5, 2.5 and $1.25 \mu \mathrm{g} / \mathrm{mL}$ ) with M199 containing 1\% insulin-transferrin-Se (ITS; Sigma-Aldrich, St. Louis, MO, USA) and 1\% penicillin-streptomycin, added into 96-well-plate and incubated for $48 \mathrm{~h}$. Cell viability was performed by quantitative colorimetric assay with 3-(4,5-Dimethylthiazol-2-yl)-2,5-diphenyltetrazolium bromide (MTT) method. Briefly, the medium was discarded, $25 \mu \mathrm{L}$ of MTT solution was added to each well and incubated for $4 \mathrm{~h}$ at $37^{\circ} \mathrm{C}$. The MTT was discarded and $150 \mu \mathrm{L}$ of DMSO was added to each well for $30 \mathrm{~min}$. With the help of microplate reader, the absorbance was measured at $490 \mathrm{~nm}$ and cell viability was calculated according to the absorbance value.

\subsection{P4, cAMP and PKA assay}

The P4, cAMP and PKA levels were determined by ELISA. 2 mL granulosa cells were seeded into a 6-well-plate at a density of $1 \times 10^{6} / \mathrm{mL}$ in M199 with $10 \%$ FBS and $1 \%$ penicillin-streptomycin. After $24 \mathrm{~h}$ of incubation, 5, 2.5 and $1.25 \mu \mathrm{g} / \mathrm{mL}$ of Ost were added into the 6-well-plate. For P4, plates were respectively incubated for $6,12,18$ and $24 \mathrm{~h}$ and for cAMP and PKA assay plates were incubated for $24 \mathrm{~h}$. P4 (in the cell culture supernatant), cAMP and PKA (in cell lysates) were measured using chicken P4, cAMP and PKA ELISA kit (Bluegene, Shanghai, China), respectively according to the manufacturer's instructions. 8-Bromo-cAMP (Topscience, Shanghai, China) was used as a positive control.

\subsection{Extraction of RNA and Quantitative Real-Time PCR}

Cell samples were prepared as described in a section of cAMP ELISA. From the granulosa cells total RNA was extracted and reverse transcribed to cDNA using RNAiso Plus (Takara, Dalian, Liaoning, China) and PrimeScript ${ }^{\mathrm{TM}}$ RT reagent Kit with gDNA Eraser (Takara, Dalian, Liaoning, China), respectively. The CDS regions of chicken origin PCNA, StAR, P450scc, 3 $\beta$-HSD and $\beta$-actin were searched from the NCBI database. The respective primers were designed with Prime Premier 5 and synthesized by BGI (Beijing, China), as shown in Table 1. Then, qRT-PCR was performed using SYBR Green qPCR Master Mix (Bimake, Shanghai, China) by ABI 7500 real-time PCR machine. The relative quantities of StAR, P450scc, 3 $\beta$-HSD and PCNA gene were calculated using $2^{-\Delta \Delta \mathrm{Ct}}$ method, with $\beta$-actin used as a house-keeping gene. 
Table 1. The primer sequences used in the present study.

\begin{tabular}{cccc}
\hline Gene & $\begin{array}{c}\text { cDNA } \\
\text { Reference }\end{array}$ & Primer Sequences $\left(5^{\prime} \rightarrow \mathbf{3}^{\prime}\right)$ & Annealing Temperature \\
\hline & & F: ATGAAGCCCAGAGCAAAAGA & \\
R: GGGGTGTTGAAGGTCTCAAA & \\
$\beta$-Actin & NM_205518 & F: AGGGTTGGGAAGGACACTCT & $60^{\circ} \mathrm{C}$ \\
StAR & NM_204686 & F: ATACATGTGGGGCCGTTCTC & $60^{\circ} \mathrm{C}$ \\
P450scc & NM_001001756 & R: TCGCTTTGCCTTGGAGTCTGTG & $60^{\circ} \mathrm{C}$ \\
33-HSD & D43762 & F: GCTTTGCCTTGGAGTCTGTG & $60^{\circ} \mathrm{C}$ \\
PCNA & NM_204170.2 & R: TCGGTGCTCTTGCGTTGC & $60^{\circ} \mathrm{C}$ \\
& & F: ATGGGCGTCAACCTAAACAG & \\
\hline
\end{tabular}

\subsection{Western Blot}

Cell samples were prepared as described in a section of cAMP ELISA. Protein concentrations of cell lysates were evaluated using a bicinchoninic acid (BCA)protein concentration detection kit (Beyotime, Shanghai, China). Next, $50 \mu \mathrm{g}$ proteins were loaded and separated using $10 \%$ sodium dodecyl sulfate-polyacrylamide gel (SDS-PAGE) and transferred to a membrane of polyvinylidene difluoride (PVDF, $0.22 \mu \mathrm{m}$ ). The membrane was then blocked with Tris-buffered Tween 20 (TBST) with $5 \%$ non-fat dry milk. Western blot analysis was used to determine protein level of StAR (diluted 1:1000 with TBST, $4{ }^{\circ} \mathrm{C}$ overnight; Bioss, Beijing, China; Catalog number: A00051-1), P450scc (diluted 1:1000 with TBST, $4^{\circ} \mathrm{C}$ overnight; Bioss, Beijing, China; Catalog number: PB0983), 3 $\beta$-HSD (diluted 1:1000 with TBST, $4^{\circ} \mathrm{C}$ overnight; Bioss, Beijing, China; Catalog number: A02856-2) and $\beta$-actin (diluted 1:4000 with TBST, room temperature 2h; Proteintech, Wuhan, Hubei, China; Catalog number: 66009-1-Ig). The membrane was three times washed with TBST and probed with HRP-conjugated secondary antibody. At the end, the proteins of interest were detected using an enhanced chemiluminescence system (Boster, Wuhan, Hubei, China). Image J software was used to analyze gray scales of Western blot images.

\subsection{ROS Assay}

The granulosa cells $(0.1 \mathrm{~mL})$ were seeded into a 96-well-plate with a density of $8 \times 10^{5} / \mathrm{mL}$ in $10 \%$ FBS and 1\% penicillin-streptomycin mixed in M199 and incubated for $24 \mathrm{~h}$. Next, 5, 2.5 and $1.25 \mu \mathrm{g} / \mathrm{mL}$ of Ost were added and incubated for another $24 \mathrm{~h}$. Normal control and Rosup positive control were set up simultaneously. The ROS level in the cell lysates were detected by ROS Assay Kit (Beyotime, Shanghai, China) following manufacturer's instructions. Briefly, the probe of DCFH-DA was diluted at 1:1000 with M199 and incubated for $20 \mathrm{~min}$ at $37^{\circ} \mathrm{C}$. After washing with M199 three times, cell fluorescence intensity was measured with the help of microplate reader at $488 \mathrm{~nm}$ and $525 \mathrm{~nm}$ excitation wavelength emission wavelength, respectively.

\subsection{Statistical Analyses}

Three experimental replicates were displayed and data are expressed as means \pm SEM. One-way ANOVA was used to perform the statistical analysis followed by Bonferroni's Multiple Comparison Test implemented in Graphad Prism 5 software (GraphPad Software, San Diego, CA, USA). *,**, *** mean $p<0.05, p<0.01$ and $p<0.001$, respectively.

\section{Results}

\subsection{Morphology of Granulosa Cells}

We observed morphology of granulosa cells at 24,48 and $72 \mathrm{~h}$ after seeding the cells in the plates (Figure 1). The granulosa cells adhered to the surface of the plates and were able to grow within $24 \mathrm{~h}$. 
The cells were irregular in shape and the pseudopods were connected to each other to aggregate and grow. Post 48 and $72 \mathrm{~h}$ of incubation, the granulosa cells were proliferated approximately $70 \%$ and 100\%, respectively. The granulosa cells identity was confirmed by FSHR staining. The representative images of the fluorescence staining of FSHR in cells were shown in Figure 2. Strong staining was observed indicating the high expression of FSHR in the isolated granulosa cells.
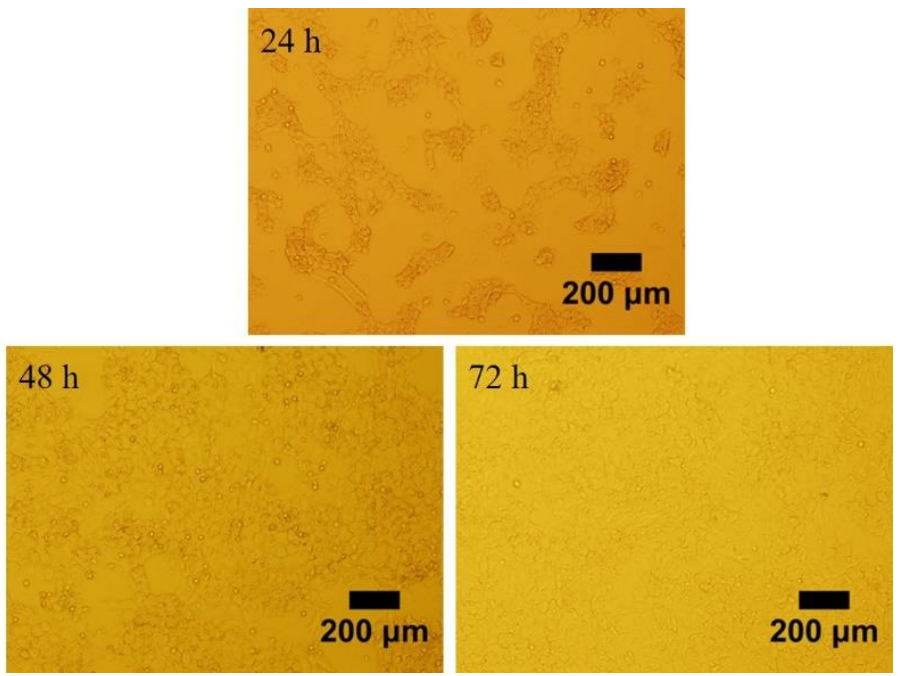

Figure 1. The preovulatory follicles of Hen's granulosa cells cultured for 24,48 and $72 \mathrm{~h}$ of post isolation. Scale bar, $200 \mu \mathrm{m}$.

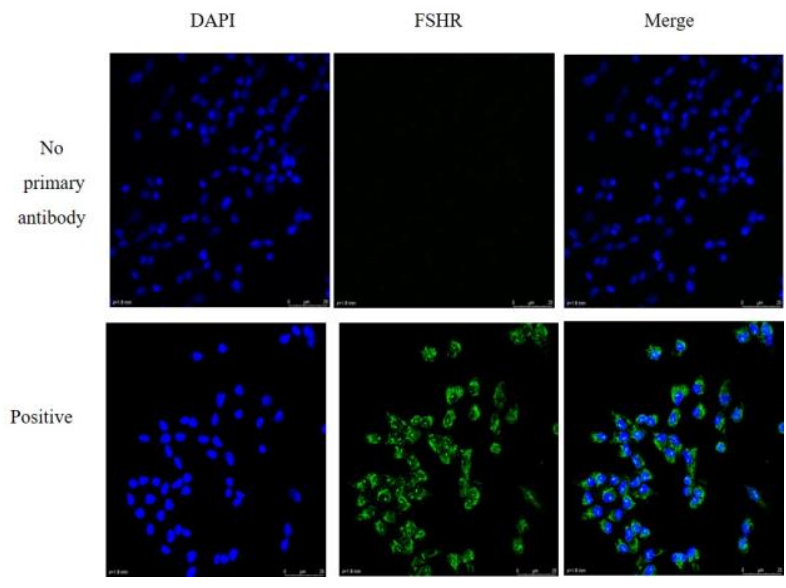

Figure 2. Fluorescence immunostaining for follicle-stimulating hormone receptor (FSHR) in granulosa cells. 4',6-diamidino-2-phenylindole (DAPI )staining for nucleus (blue); immunoblotting for anti-FSHR cytoplasm (green); PBS for no primary antibody. Scale bar, $20 \mu \mathrm{m}$.

\subsection{Effect of Ost on Viability of Granulosa Cells}

Viability of granulosa cells were analyzed by MTT method and the results are shown in Figure 3. Compared with the control group, the cell viability was significantly decreased in groups treated with Ost at 80,40, 20 and $10 \mu \mathrm{g} / \mathrm{mL}$. Therefore, low concentrations of Ost (5, 2.5 and $1.25 \mu \mathrm{g} / \mathrm{mL})$ were used in the follow up study in order to keep suitable cell viability. 


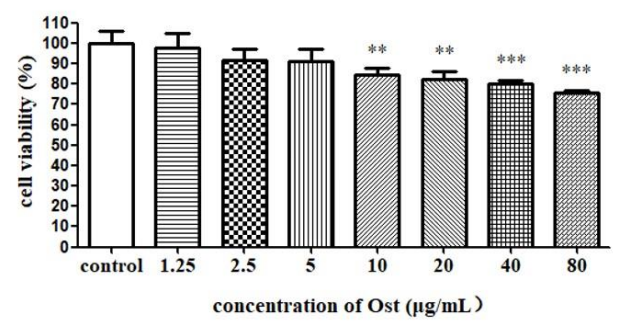

Figure 3. The cell viability of granulosa cells after treatment with Ost for $48 \mathrm{~h}$. MTT was used to determine the cell viability. Data were expressed as Mean \pm SEM. ${ }^{* *} p<0.01{ }^{* * *} p<0.001$.

\subsection{Effect of Ost on P4 Secretion in Granulosa Cells}

In the supernatant, progesterone was measured at different concentrations $(5,2.5$ and $1.25 \mu \mathrm{g} / \mathrm{mL})$ and were respectively measured at $6,12,18$ and $24 \mathrm{~h}$. A significant increase was observed in P4 secretion after $24 \mathrm{~h}$ of incubation with $2.5 \mu \mathrm{g} / \mathrm{mL}$ of Ost only $(p<0.05$; Figure 4$)$. Therefore, $24 \mathrm{~h}$ treatment was selected for the follow up study.

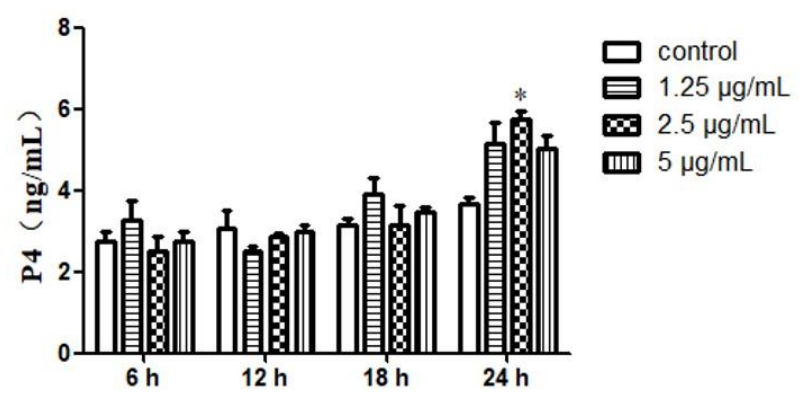

Figure 4. The level of $\mathrm{P} 4$ secretion in cultured granulosa cells treated with Ost at various time points.

ELISA was used to determine the content of P4. Data were expressed as Mean \pm SEM. ${ }^{*} p<0.05$.

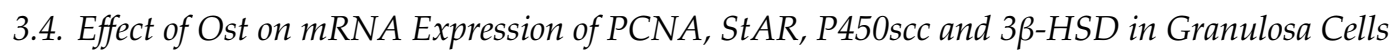

The results of qRT-PCR showed that PCNA mRNA expression was not significantly affected in Ost-treated groups as compared to the control group (Figure 5). StAR mRNA expression was significantly increased in the group treated with Ost at $2.5 \mu \mathrm{g} / \mathrm{mL}(p<0.01$; Figure $6 \mathrm{~A})$. P450scc and $3 \beta$-HSD were significantly increased in all the three groups treated with Ost at $5,2.5,1.25 \mu \mathrm{g} / \mathrm{mL}$ (Figure 6B,C). These results show that StAR, P450scc and 3 $\beta$-HSD mRNA expression were up-regulated in chicken granulosa cells after $24 \mathrm{~h}$ of $2.5 \mu \mathrm{g} / \mathrm{mL}$ Ost treatment.

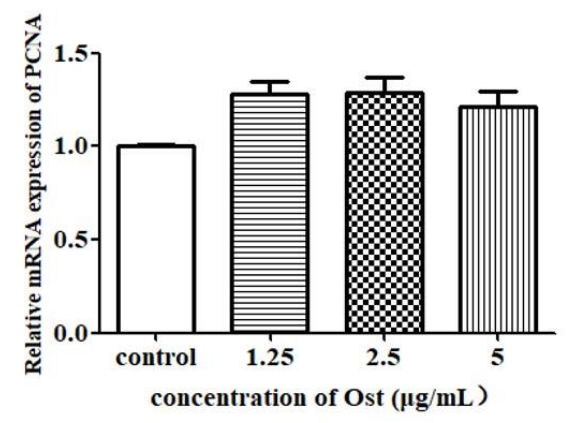

Figure 5. Effect of Ost on PCNA mRNA expression in granulosa cells. qRT-PCR was performed and $2^{-\triangle \Delta \mathrm{Ct}}$ method was used for analysis. Data were expressed as Mean $\pm \mathrm{SEM}$. 
A

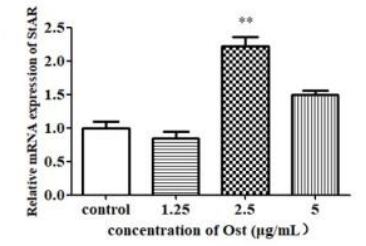

B

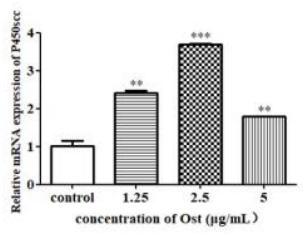

C

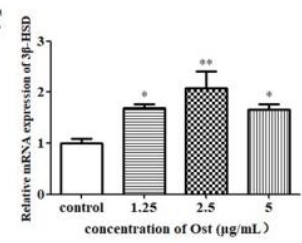

Figure 6. The mRNA expression of StAR (A), P450scc (B) and 3 $3-\mathrm{HSD}(\mathbf{C})$ in granulosa cells treated with Ost for $24 \mathrm{~h}$. qRT-PCR was performed and $2^{-\Delta \Delta \mathrm{Ct}}$ method was used for analysis. Data were expressed as Mean \pm SEM. ${ }^{*} p<0.05,{ }^{* *} p<0.01,{ }^{* * *} p<0.001$.

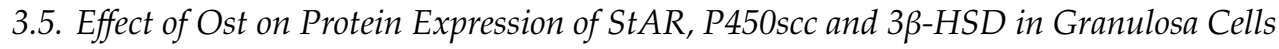

The expression of StAR, P450scc and 3 $\beta$-HSD proteins in granulosa cells were significantly increased in western blot analysis (Figure 7A,C). The results confirm that the expression of StAR, P450scc and 3 $\beta$-HSD proteins were consistent with that of mRNA expression in chicken granulosa cells after $24 \mathrm{~h}$ of $2.5 \mu \mathrm{g} / \mathrm{mL}$ Ost treatment.

A

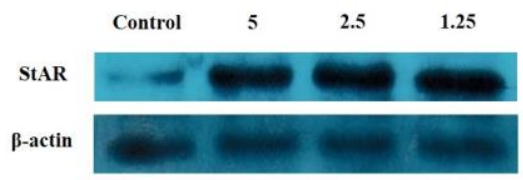

B

\section{P450sce \\ $\beta$-actin}

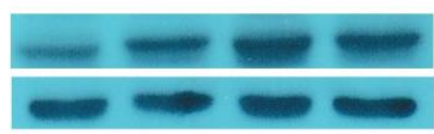

C

3B-HSD

$\beta$-actin
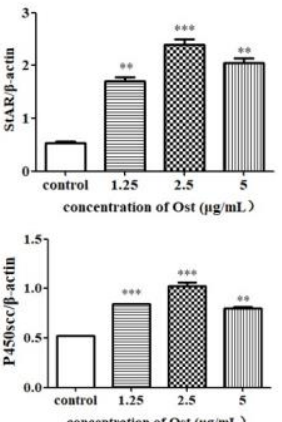

concentration or Ost(ug $\mathrm{mL}$ )

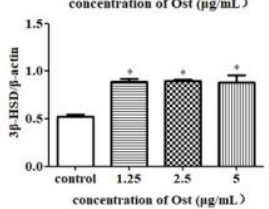

Figure 7. Western blot analysis of StAR (A), P450scc (B), and 3 $\beta-H S D(C)$ protein expression in granulosa cells after treatment with Ost $(5,2.5,1.25 \mu \mathrm{g} / \mathrm{mL})$ for $24 \mathrm{~h}$. Image J software was used to analyze gray scales of Western blot images. Data were expressed as Mean \pm SEM. ${ }^{*} p<0.05,{ }^{* *} p<0.01$, *** $p<0.001$.

\subsection{Effect of Ost on cAMP and PKA Secretion in Granulosa Cells}

There was no significant difference in both cAMP and PKA secretion in cell lysates after $24 \mathrm{~h}$ of Ost treatment (Figure 8). The positive control 8-Bromo-cAMP increased both cAMP and PKA contents $(p<0.01)$. 

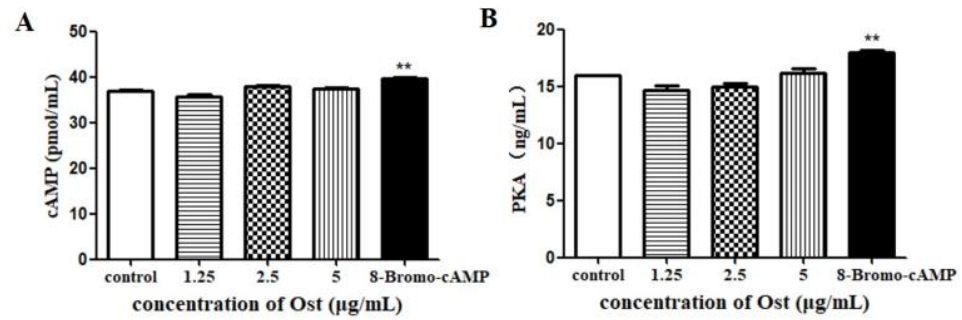

Figure 8. The level of $\mathrm{cAMP}(\mathbf{A})$ and $\mathrm{PKA}(\mathbf{B})$ in granulosa cells lysates were determined by ELISA. 8-Bromo-cAMP (Topscience, Shanghai, China) was used as a positive control. Data were expressed as Mean \pm SEM. ${ }^{* *} p<0.01$.

\subsection{Effect of Ost on ROS Expression in Granulosa Cells}

After $24 \mathrm{~h}$ of treatment, no significant difference was seen in ROS level between control and Ost-treated groups (Figure 9). The result indicated that Ost does not up-regulate P4 by down-regulating ROS after $24 \mathrm{~h}$ of treatment.

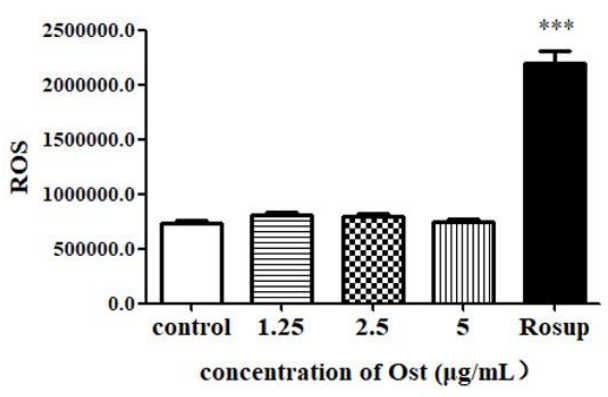

Figure 9. The production of reactive oxygen species (ROS) in granulosa cells post $24 \mathrm{~h}$ of treatment with Ost with Rousp was set as a positive control for ROS test. Data were expressed as Mean \pm SEM. *** $p<0.001$.

\section{Discussion}

In poultry, $\mathrm{P} 4$ is a hormone produced by granulosa cells which is obtained from pre-ovulatory follicles and regulates diverse reproductive events [5-7]. The study on regulation of progesterone synthesis and secretion has both theoretical and practical importance for the pre-peak phase and maximum output of peak egg production in laying hens. At present, Ost has been reported that can negatively affect the growth of some cancer cells [21-23], osteoporosis [24,25], inflammation [26-28] and possess estrogen-like effects [3,4]. But there are few research reports on the effect of Ost on reproductive endocrinology. The main purpose of this study was to check the effect of Ost on the regulation of P4 secretion. We tested three doses $(5,2.5,1.25 \mu \mathrm{g} / \mathrm{mL})$ of Ost with four incubation time points $(6,12,18$, $24 \mathrm{~h}$ ). The results show that progesterone in granulosa cells obtained from pre-ovulatory follicles can be specifically upregulated at $24 \mathrm{~h}$ of incubation with $2.5 \mu \mathrm{g} / \mathrm{mL}$ of Ost.

Cell proliferation is one of the key factors for the increase of progesterone secretion. PCNA is a nuclear protein which is necessary for DNA synthesis in eukaryotic cells, synthesized and stored in the nucleus [14]. This study revealed no significant difference in PCNA expression and thus confirmed that P4 up-regulation by Ost does not occur through regulation of cell proliferation. Xiao et al. [13] investigated the effects of genistein on $\mathrm{P} 4$ secretion in chicken granulosa cells harvested from follicles in vitro follocles, and the results show that P4 secretion was significantly stimulated by genistein through upregulation of P450scc, $3 \beta$-HSD and StAR gene transcription in cultured granulosa cells but the PCNA protein expression was not affected. Therefore, in our study, we focused on key enzymes in regulating the synthesis and secretion of progesterone.

It is well known that cholesterol conversion to P4 is catalyzed by three key enzymes. Firstly, cholesterol enters into mitochondria from the outer membrane with the help of StAR. Then, the side 
chain cleavage of cholesterol was removed by P450scc to form pregnenolone which is transported out of the mitochondria. Finally, pregnenolone is converted to P4 by $3 \beta-\mathrm{HSD}[29,30]$. Kisspeptin-10 can significantly stimulate P4 secretion and up-regulate StAR, P450scc and 3 $\beta$-HSD gene transcription, but can't up-regulate protein expression of StAR, P450scc and 3 $\beta$-HSD in granulosa cells obtained from preovulatory follicles [31]. In our study, $24 \mathrm{~h}$ treatment of $2.5 \mu \mathrm{g} / \mathrm{mL}$ Ost has significantly up-regulated P4 by elevating StAR, P450scc and 3 $\beta$-HSD expressions both at mRNA and protein level.

Steroid hormones synthesis is monitored by gonadotropins through a classical cAMP/PKA pathway. Activation of cAMP/PKA signaling promotes StAR, P450scc and 3 $\beta$-HSD expressions $[15,16]$. Wu et al. reported that steroidogenesis is inhibited by $\mathrm{T} 2$ toxin through suppressing of cAMP-PKA pathways and StAR is the main target for T-2-toxin [32]. Our results show that the contents of cAMP and PKA in cell lysates were not significantly changed post incubation of $24 \mathrm{~h}$ with Ost at three different concentrations. These results suggested that $\mathrm{CAMP} / \mathrm{PKA}$ is not the main target of Ost.

The process of progesterone synthesis is accompanied by mitochondrial electron transportation and oxidative phosphorylation. The mitochondrial membrane potential, $\mathrm{H}+$ potential between the inner membrane and matrix played crucial roles in steroid hormones synthesis [33,34]. In the process of biological oxidation, most of the hydrogen removed by each substance is accepted by coenzymes. The hydrogen from these coenzymes passes through a series of electron transportations on the inner membrane of mitochondria to oxygen molecules to form water. ROSs are mainly produced by mitochondria during electron transport [35]. There have been several reports showed that ROSs can inhibit steroid hormone synthesis [17-19]. In this study, no significant difference was found at the level of ROS between treated and non-treated groups indicating that $2.5 \mu \mathrm{g} / \mathrm{mL}$ Ost did not play a role in ROS regulation.

\section{Conclusions}

This was a base line study which reported that Ost significantly regulated P4 secretion through up-regulation of P450scc, $3 \beta-\mathrm{HSD}$ and StAR gene and protein expression. Cell proliferation, cAMP/PKA and ROS were not the main target of Ost to regulate progesterone secretion. In the future, we will further elucidate the target of Ost from hormone regulation. These results lay a theoretical foundation that Osthole may be developed as extending the peak period of laying eggs and increasing the egg yield of laying hens.

Author Contributions: Conceptualization, N.S.; Y.S.; and H.L.; methodology, Y.Z.; and N.S.; validation, H.L.; software and formal analysis, Y.Y.; and P.S.; Investigation and data curation, Y.Z.; Y.H.; Y.Y.; and P.S.; resources, Y.S.; and H.L.; writing—original draft preparation, Y.Z.; and N.S.; writing—review and editing, A.K., X.Z.; and J.G.; project administration, N.S.; funding acquisition, Y.S.; and H.L. All authors have read and agreed to the published version of the manuscript.

Funding: This research was funded by the National Key R\&D Program of China (Grant Number 2017YFD0501500) and Key Research and Development Plan of Shanxi Province (Grant Number 201803D221023-3).

Conflicts of Interest: The authors declare no conflict of interest.

\section{References}

1. Chen, J.; Ying, G.G.; Deng, W.J. Antibiotic residues in food: Extraction, analysis, and human health concerns. J. Agric. Food. Chem. 2019, 67, 7569-7586. [CrossRef] [PubMed]

2. Zafar, S.; Sarfraz, I.; Rasul, A.; Shah, M.A.; Hussain, G.; Zahoor, M.K.; Shafiq, N.; Riaz, A.; Selamoglu, Z.; Sarker, S. Osthole: A multifunctional natural compound with potential anticancer, antioxidant and anti-inflammatory Activities. Mini-Rev. Med. Chem. 2020. [CrossRef] [PubMed]

3. Zhang, X.W.; Zhang, D.S.; Xue, G.P.; Zhao, Y.J.; Jin, C. Experimental research on estrogenic effect of Osthole on rats. Chin. Pharm. Bull. 2013, 29, 1031-1032.

4. Pan, Z.Q.; Fang, Z.Q.; Lu, W.L.; Liu, X.M.; Zhang, Y.Y. Osthole, a coumadin analog from Cnidium monnieri (L.) Cusson, stimulates corticosterone secretion by increasing steroidogenic enzyme expression in mouse Y1 adrenocortical tumor cells. J. Ethnopharmacol. 2015, 175, 456-462. [CrossRef] 
5. Ghanem, K.; Johnson, A.L. Response of hen pre-recruitment ovarian follicles to follicle stimulating hormone, in vivo. Gen. Comp. Endocrinol. 2019, 270,41-47. [CrossRef]

6. Huang, E.S.; Kao, K.J.; Nalbandov, A.V. Synthesis of sex steroids by cellular components of chicken follicles. Biol. Reprod. 1979, 20, 454-461. [CrossRef]

7. Woods, D.C.; Schorey, J.S.; Johnson, A.L. Toll-like receptor signaling in hen ovarian granulosa cells is dependent on stage of follicle maturation. Reproduction 2009, 137, 987-996. [CrossRef] [PubMed]

8. Johnson, A.L.; Solovieva, E.V.; Bridgham, J.T. Relationship between steroidogenic acute regulatory protein expression and progesterone production in hen granulosa cells during follicle development. Biol. Reprod. 2002, 67, 1313-1320. [CrossRef] [PubMed]

9. Meng, B.; Cao, Z.; Gai, Y.; Liu, M.; Gao, M.; Chen, M.; Ning, Z.; Luan, X. Effects of recombinant goose adiponectin on steroid hormone secretion in Huoyan geese ovarian granulosa cells. Anim. Reprod. Sci. 2019, 205, 34-43. [CrossRef]

10. Hosoya, T.; Otsuka, F.; Nakamura, E.; Terasaka, T.; Inagaki, K.; Tsukamoto-Yamauchi, N.; Hara, T.; Toma, K.; Komatsubara, M.; Makino, H. Regulatory role of BMP-9 in steroidogenesis by rat ovarian granulosa cells. J. Steroid Biochem. Mol. Biol. 2015, 147, 85-91. [CrossRef] [PubMed]

11. Ma, Y.; Gong, Y.J.; Xu, Q.Q.; Zou, X. Molecular mechanism of mercuric chloride inhibiting progesterone secretion in ovarian granulosa cells of laying hens. J. Anim. Physiol. Anim. Nutr. 2018, 102, 1533-1542. [CrossRef]

12. Li, J.; Luo, W.; Huang, T.; Gong, Y. Growth differentiation factor 9 promotes follicle-stimulating hormone-induced progesterone production in chicken follicular granulosa cells. Gen. Comp. Endocrinol. 2019, 276, 69-76. [CrossRef] [PubMed]

13. Xiao, Y.Q.; Shao, D.; Tong, H.B.; Shi, S.R. Genistein increases progesterone secretion by elevating related enzymes in chicken granulosa cells. Poult. Sci. 2019, 98, 1911-1917. [CrossRef]

14. Strzalka, W.; Ziemienowicz, A. Proliferating cell nuclear antigen (PCNA): A key factor in DNA replication and cell cycle regulation. Ann. Bot. 2011, 107, 1127-1140. [CrossRef]

15. Allan, G.F.; Leng, X.; Tsai, S.Y.; Weigel, N.L.; Edwards, D.P.; Tsai, M.J.; O'Malley, B.W. Hormone and antihormone induce distinct conformational changes which are central to steroid receptor activation. J. Biol. Chem. 1992, 267, 19513-19520.

16. Johnson, A.L.; Lee, J. Granulosa cell responsiveness to follicle stimulating hormone during early growth of hen ovarian follicles. Poult. Sci. 2016, 95, 108-114. [CrossRef] [PubMed]

17. Askoxylaki, M.; Siristatidis, C.; Chrelias, C.; Vogiatzi, P.; Creatsa, M.; Salamalekis, G.; Vrantza, T.; Vrachnis, N.; Kassanos, D. Reactive oxygen species in the follicular fluid of subfertile women undergoing in vitro fertilization: A short narrative review. J. Endocrinol. Investig. 2013, 36, 1117-1120.

18. Zheng, W.; Feng, N.; Wang, Y.; Noll, L.; Xu, S.; Liu, X.; Lu, N.; Zou, H.; Gu, J.; Yuan, Y.; et al. Effects of zearalenone and its derivatives on the synthesis and secretion of mammalian sex steroid hormones: A review. Food Chem. Toxicol. 2019, 126, 262-276. [CrossRef]

19. Abidi, P.; Zhang, H.; Zaidi, S.M.; Shen, W.J.; Leers-Sucheta, S.; Cortez, Y.; Han, J.; Azhar, S. Oxidative stress-induced inhibition of adrenal steroidogenesis requires participation of p38 mitogen-activated protein kinase signaling pathway. J. Endocrinol. 2008, 198, 193-207. [CrossRef] [PubMed]

20. Gilbert, A.B.; Evans, A.J.; Perry, M.M.; Davidson, M.H. A method for separating the granulosa cells, the basal lamina and the theca of the preovulatory ovarian follicle of the domestic fowl (Gallus domesticus). J. Reprod. Fertil. 1977, 50, 179-181. [CrossRef]

21. Su, J.; Zhang, F.; Li, X.; Liu, Z. Osthole promotes the suppressive effects of cisplatin on NRF2 expression to prevent drug-resistant cervical cancer progression. Biochem. Biophys. Res. Commun. 2019, 514, 510-517. [CrossRef]

22. Dai, X.; Yin, C.; Zhang, Y.; Guo, G.; Zhao, C.; Wang, O.; Xiang, Y.; Zhang, X.; Liang, G. Osthole inhibits triple negative breast cancer cells by suppressing STAT3. J. Exp. Clin. Cancer Res. 2018, 37, 322. [CrossRef] [PubMed]

23. Le, Z.T.; Wang, H.F.; Ren, T.; Shao, Z.Y.; Yuan, R.Y.; Gao, Y.; Zhang, Y.J.; Wang, X.A.; Liu, Y.B. Osthole inhibits the progression of human gallbladder cancer cells through JAK/STAT3 signal pathway both in vitro and in vivo. Anticancer Drugs 2019, 30, 1022-1030. 
24. Ma, Y.; Wang, L.; Zheng, S.; Xu, J.; Pan, Y.; Tu, P.; Sun, J.; Guo, Y. Osthole inhibits osteoclasts formation and bone resorption by regulating NF- $\mathrm{KB}$ signaling and NFATc1 activations stimulated by RANKL. J. Cell. Biochem. 2019, 120, 16052-16061. [CrossRef]

25. Wang, P.; Ying, J.; Luo, C.; Jin, X.; Zhang, S.; Xu, T.; Zhang, L.; Mi, M.; Chen, D.; Tong, P.; et al. Osthole promotes bone fracture healing through activation of BMP signaling in chondrocytes. Int. J. Biol. Sci. 2017, 13, 996-1007. [CrossRef] [PubMed]

26. Xu, R.; Liu, Z.; Hou, J.; Huang, T.; Yang, M. Osthole improves collagen-induced arthritis in a rat model through inhibiting inflammation and cellular stress. Cell. Mol. Biol. Lett. 2018, 23, 19. [CrossRef] [PubMed]

27. Kong, L.; Yao, Y.; Xia, Y.; Liang, X.; Ni, Y.; Yang, J. Osthole alleviates inflammation by down-regulating NF- $\mathrm{BB}$ signaling pathway in traumatic brain injury. Immunopharmacol. Immunotoxicol. 2019, 41, 349-360. [CrossRef] [PubMed]

28. Fan, H.; Gao, Z.; Ji, K.; Li, X.; Wu, J.; Liu, Y.; Wang, X.; Liang, H.; Liu, Y.; Li, X.; et al. The in vitro and in vivo anti-inflammatory effect of osthole, the major natural coumarin from Cnidium monnieri (L.) Cuss, via the blocking of the activation of the NF-kB and MAPK/p38 pathways. Phytomedicine 2019, 58, 152864. [CrossRef] [PubMed]

29. Kuai, Y.; Gao, X.; Yang, H.; Luo, H.; Xu, Y.; Liu, C.; Yu, H.; Wang, Y.; Zhang, C.; Ma, X.; et al. Pentachloronitrobenzene alters progesterone production and primordial follicle recruitment in cultured granulosa cells and rat ovary. Biol. Reprod. 2020, 102, 511-520. [CrossRef]

30. Fujita, S.; Hasegawa, T.; Nishiyama, Y.; Fujisawa, S.; Nakano, Y.; Nada, T.; Iwata, N.; Kamada, Y.; Masuyama, H.; Otsuka, F. Interaction between orexin A and bone morphogenetic protein system on progesterone biosynthesis by rat granulosa cells. J. Steroid Biochem. Mol. Biol. 2018, 181, 73-79. [CrossRef]

31. Xiao, Y.; Ni, Y.; Huang, Y.; Wu, J.; Grossmann, R.; Zhao, R. Effects of kisspeptin-10 on progesterone secretion in cultured chicken ovarian granulosa cells from preovulatory (F1-F3) follicles. Peptides 2011, 32, 2091-2097. [CrossRef] [PubMed]

32. Wu, J.; Tu, D.; Yuan, L.Y.; Yi, J.; Tian, Y. T-2 toxin regulates steroid hormone secretion of rat ovarian granulosa cells through cAMP-PKA pathway. Toxicol. Lett. 2015, 232, 573-579. [CrossRef] [PubMed]

33. Boujrad, N.; Hudson, J.R.; Papadopoulos, V. Inhibition of hormone-stimulated steroidogenesis in cultured Leydig tumor cells by a cholesterol-linked phosphorothioate oligodeoxynucleotide antisense to diazepam-binding inhibitor. Proc. Natl. Acad. Sci. USA 1993, 90, 5728-5731. [CrossRef]

34. Solish, S.B.; Picado-Leonard, J.; Morel, Y.; Kuhn, R.W.; Mohandas, T.K.; Hanukoglu, I.; Miller, W.L. Human adrenodoxin reductase: Two mRNAs encoded by a single gene on chromosome 17cen-q25 are expressed in steroidogenic tissues. Proc. Natl. Acad. Sci. USA 1988, 85, 7104-7108. [CrossRef] [PubMed]

35. Miller, W.L. Minireview: Regulation of steroidogenesis by electron transfer. Endocrinology 2005, 146, $2544-2550$. [CrossRef] [PubMed]

Publisher's Note: MDPI stays neutral with regard to jurisdictional claims in published maps and institutional affiliations.

(C) 2020 by the authors. Licensee MDPI, Basel, Switzerland. This article is an open access article distributed under the terms and conditions of the Creative Commons Attribution (CC BY) license (http://creativecommons.org/licenses/by/4.0/). 